\title{
EFISIENSI PENGGUNAAN FAKTOR-FAKTOR PRODUKSI PADA USAHATANI PADI SUBAK CARIK TANGIS WONGAYA GEDE TABANAN - BALI
}

\section{The Efficiency of Using Production Factors for Rice Agricultural Businnes in Subak Carik Tangis, Wongaya Gede, Tabanan-Bali}

\author{
I Gusti Ngurah Yuri Putra, Made Antara, Dewa Putu Oka Suardi
}

Program Studi Magister Agribisnis, Fakultas Pertanian, Universitas Udayana, Bali, Indonesia

Email: yuriprawira@yahoo.com

\begin{abstract}
Farming development have direction to improve production in order to fulfil food need and industry need in domestic, to improve export, to extend job opportunity and to push business opportunity at same time to improve farmer income so that will be expected to analyze the effect of production factors covering farm wide, fertilizer, pesticide, labour and technology, toward improvement on farm production result aand to analysis technical efficiency, price and economic, production factors have effect on paddy production at Subak Carik Tangis, Tabanan-Bali. Population in this study was the farmer in the Subak Carik Tangis as much 137 people. Sampling in this study was proportional random sampling as much 58 farmer. Data analysi method by using production faunction of Cobb-Douglas that estimated toward production factor by using multiple regression analysis with ordinary least square $(O L S)$ regression. The results showed that simultaneously almost all rice production factors within the Cobb-Douglas production function in rice farming have a significant effect on rice production. Seed production factors, land area, urea fertilizer, and technology have significant effect on rice production. Matador pesticides and labour have no significant effect on rice production. Result of technical efficiency analysis, all production factors are technically efficient, seed production factor, land area, fertilizer, pesticide, and labour technically efficient. Viewed from the efficiency of prices, all production factors are not efficient or efficient, in which case the use of inputs is used excessively so it needs to be reduced to obtain maximum profit. Viewed from the economic efficiency all production factors are not efficient that its means the use of input is not optimal, so farmers have not gained the maximum profit. If farmers want rice yields to have a real effect, then rice farmers in Subak Carik Tangis Wongaya Gede Tabanan need to think about the production factors that will be used to obtain profits that will increase rice production maximally. In conducting rice farming, the government needs to pay attention to the factors that will affect on rice production so as to achieve efficiency in rice farming. The use of production factors needs to be done appropriately, so that farmers are able to achieve the level of efficiency. For next researchers who will conduct research in Subak Carik Tangis, it is necessary to conduct further research on "Efficiency of usage of organic rice production factor" and "marketing strategy of rice production result especially Red Rice".
\end{abstract}

Keywords: Efficiency, Production, Rice

\begin{abstract}
ABSTRAK
Pembangunan pertanian memiliki arah untuk meningkatkan produksi dalam rangka memenuhi kebutuhan pangan dan kebutuhan industri di dalam negeri, untuk meningkatkan ekspor, untuk memperluas kesempatan kerja dan untuk mendorong peluang bisnis pada saat yang sama untuk meningkatkan pendapatan petani sehingga diharapkan untuk menganalisa efek dari produksi faktor meliputi luas lahan, pupuk, pestisida, tenaga kerja dan teknologi, terhadap peningkatan hasil produksi pertanian dan untuk analisis efisiensi teknis, harga dan ekonomi, faktor produksi berpengaruh terhadap produksi padi di Subak Carik Tangis, Tabanan - Bali. Populasi dalam penelitian ini adalah petani di Subak Carik Tangis sebanyak 137 orang. Pengambilan sampel dalam penelitian ini adalah proporsional random sampling sebanyak 58 petani. Metode analisis data dengan menggunakan penghitungan produksi Cobb-Douglas yang diperkirakan terhadap faktor produksi dengan menggunakan analisis regresi berganda dengan regresi ordinary least square (OLS). Hasil penelitian menunjukkan bahwa secara bersamaan hampir semua faktor produksi padi dalam fungsi produksi Cobb-Douglas dalam usahatani padi memiliki pengaruh yang signifikan terhadap produksi padi. Faktor produksi benih, luas lahan, pupuk urea, dan teknologi berpengaruh nyata terhadap produksi padi. Pestisida matador dan tenaga kerja tidak berpengaruh signifikan terhadap produksi beras. Hasil analisis efisiensi teknis, semua faktor produksi secara teknis efisien, faktor produksi benih, luas lahan, pupuk, pestisida, dan tenaga teknis yang efisien. Dilihat dari efisiensi harga, semua faktor produksi tidak efisien
\end{abstract}


atau efisien, dalam hal ini penggunaan input digunakan secara berlebihan sehingga perlu dikurangi untuk mendapatkan keuntungan maksimal. Dilihat dari efisiensi ekonomi semua faktor produksi tidak efisien yang artinya penggunaan input tidak optimal, sehingga petani belum mendapatkan keuntungan yang maksimal. Jika petani ingin hasil panen padi berpengaruh nyata, maka petani padi di Subak Carik Tangis Wongaya Gede Tabanan perlu memikirkan faktor-faktor produksi yang akan digunakan untuk mendapatkan keuntungan yang akan meningkatkan produksi padi secara maksimal. Dalam melakukan usahatani padi, pemerintah perlu memperhatikan faktor-faktor yang akan mempengaruhi produksi padi sehingga mencapai efisiensi dalam usahatani padi. Penggunaan faktor produksi perlu dilakukan secara tepat, agar petani mampu mencapai tingkat efisiensi. Untuk peneliti selanjutnya yang akan melakukan penelitian di Subak Carik Tangis, perlu dilakukan penelitian lebih lanjut tentang "Efisiensi penggunaan faktor produksi padi organik" dan "strategi pemasaran hasil produksi padi khususnya Beras Merah".

Kata Kunci: Efisiensi, Produksi, Beras

\section{PENDAHULUAN}

\section{Latar Belakang}

Kenyataan yang dihadapi di Indonesia untuk melaksanakan kegiatan usaha-tani, petani dihadapkan pada beberapa keterbatasan seperti dalam hal pemilikan lahan dan modal.Walaupun demikian di era pembangunan pertanian yang berorientasi agribisnis, seorang petani dengan sumber daya yang dimiliki dapat digunakan untuk menghasilkan berbagai jenis produksi pertanian yang mempunyai nilai ekonomi tinggi, dengan demikian petani sebagai pengelola usahataninya harus berpikir bagaimana mengalokasikan sumber daya yang dimiliki untuk meningkatkan pendapatannya.

Berdasarkan pandangan tersebut, SubakCarikTangissebagaisebuahorganisasipertanian di DesaWongaya Gede merupakan salah satu organisasi pertanian tradisional yang berkeinginan untuk membangun kesejahteraan masyarakatnya melalui hasil produksi pertaniannya. Keinginan tersebut didasari atas pengalaman masa lalu yang dialami Subak Carik Tangis terkait pengairan, system irigasi sampai dengan kekeringan akibat terbatasnya sumber air yang dialaminya. Berbagai upaya kemudian digiatkan untuk membangun kembali lahan pertanian agar mampu memberikan hasil kepada petaninya.Terkait dengan Subak Carik Tangis sebagai sebuah sistem koordinasi, teknis dan penanganan seputar masalah pertanian, tentu menjadi hal penting ketika kegagalan menjadi masalah dari petani dalam organisasi tersebut.

\section{Rumusan Masalah}

Rumusan masalah dari penelitian ini adalah:

1. Bagaimana pengaruh faktorproduksi benih, luas lahan, pupuk, pestisida, tenagakerja dan teknologi terhadap peningkatan hasil produksi padi di Subak Carik Tangis Wongaya Gede Kabupaten Tabanan - Bali?

2. Bagaimana efisiensi teknis, harga, dan ekonomis faktor-faktor produksi terhadap produksi padi di Subak Carik Tangis Wongaya GedeKabupaten Tabanan - Bali?

\section{Tujuan Penelitian}

Tujuan penelitian ini adalah:

3. Menganalisis pengaruh faktor produksi meliputi luas lahan, pupuk, pestisida, tenagakerja dan teknologi terhadap peningkatan hasil produksi padi di Subak Carik Tangis Wongaya Gede Kabupaten Tabanan - Bali.

4. Menganalisis efisiensi teknis, harga, dan ekonomis faktor-faktor produksi berpengaruh terhadap produksi padi di Subak Carik Tangis Wongaya Gede, Kabupaten Tabanan-Bali

\section{KAJIAN PUSTAKA}

\section{Produksi}

Produksi diartikan sebagai penggunaan atau pemanfaatan sumber daya yang mengubah suatu komoditi menjadi komoditi lainnya yang sama sekali berbeda, baik dalam pengertian apa, dan dimana atau kapan komoditi-komoditi tersebut dialokasikan, maupun dalam pengertian apa yang dikerjakan oleh konsumen terhadap komoditi itu (Miller dan Mainers, 2000). Dengan demikian produksi itu tidak terbatas pada pembuatannya saja tetapi juga penyimpanannya, distribusi, pengangkutan, pengeceran, pemasaran kembali, upaya-upaya mensiasati lembaga regulator atau mencari celah hukum demi memperoleh keringanan pajak atau lainnya.

\section{Faktor-Faktor Produksi}

Faktor produksi disebut dengan input. Input merupakan hal yang mutlak, karena proses produksi untuk menghasilkan produktertentu dibutuhkan sejumlah faktor produksi tertentu. Misalnya untuk menghasilkan padi dibutuhkan luaslahan, pupuk, pestisida, tenagakerja dan teknologi. Proses produksi menuntut seorang pengusaha mampu menganalisis teknologi tertentu dan mengkombinasikan berbagai macam faktor produksi untuk menghasilkan sejumlah produk tertentu seefisien mungkin (Riyadi, 2007). Menurut Soekartawi (2005), ada lima faktor produksi yaitu: lahan, pupuk, pestisida, teknologi dan tenaga kerja. 


\section{KERANGKA KONSEP DAN HIPOTESIS}

\section{Kerangka Konsep Penelitian}

Faktor-faktor produksi yang digunakan sebagai subjek kajian dalam penelitian ini meliputi: benih, luas lahan, pupuk, pestisida, tenaga kerja danteknologi yang dipandang memiliki peran penting dalam meningkatkan hasil produksi sebuah kegiatan pertanian. Dengan menggunakan faktorfaktor tersebut produksi padi diwilayah ini dapat meningkat sesuai dengan harapan petani. Faktorfaktor tersebut secara kontekstual kemudian diuji dengan model Cobb-Douglas yang diterjemahkan melalui rumus regresidengan berdasarkan beberapa kriteria uji meliputi KriteriaEkonomis, KriteriaEkonometrika dan KriteriaStatistik. Pengujian selanjutnya dilakukan dengan mengukur tingkat efisiensi yang diberikan faktor-faktor produksi melalui rumusan sebagaiman disampaikan dalam bab sebelumnya.

\section{Hipotesis}

Hipotesis dalam penelitian adalah:

1. Faktor-faktor produksi yaitubenih, luas lahan, pupuk, pestisida, tenaga kerja dan teknologiberpengaruh terhadap hasil produksi padi di Subak Carik Tangis, Wongaya Gede Tabanan Bali.

2. Efisiensi teknis, harga, dan ekonomis berpengaruh terhadap produksi padi di Subak Carik Tangis, Wongaya Gede Tabanan Bali.

\section{METODE PENELITIAN}

Metode yang digunakan dalam penelitian ini yaitu metode deskriptif dan metode kuantitatif. Proses pengolahan data dilakukan menggunakan software microsoft excel dan software SPSS 20.0.

\section{HASIL DAN PEMBAHASAN}

\section{Karakteristik Responden}

Responden dari penelitian ini adalah petani di Subak Carik Tangis Wongaya Gede Tabanan Bali yang diambil sebanyak 58 orang sebagai sampel. Karakteristik responden yang berusaha diungkap dalam penelitian ini meliputi: tingkat pendidikan formal, jenis kelamin, umur responden dan jumlah anggota rumah tangga.

\section{Pengaruh Faktor Produksi Terhadap Produksi Padi}

Faktor-faktor produksi (X) terhadap produksi padi (Y). Pada tahap spesifikasi variabel, diduga faktorfaktor produksi seperti: Benih Padi $\left(\mathrm{X}_{1}\right)$, luas lahan $\left(\mathrm{X}_{2}\right)$, pupuk $\left(\mathrm{X}_{3}\right)$, pestisida $\left(\mathrm{X}_{4}\right)$, tenaga kerja $\left(\mathrm{X}_{5}\right)$ dan teknologi (D) berpengaruh terhadap produksi padi (Y). Model persamaan fungsi produksi CobbDouglas :

$\ln \mathrm{Y}=-$

$2,660+0,482 \ln \mathrm{X}_{1}^{+} 0,163 \ln \mathrm{X}_{2}+0,528 \ln \mathrm{X}_{3}+0,258 \ln \mathrm{X}_{4}$ $+0,986 \ln \mathrm{X}_{5}+0,653 \ln \mathrm{D}$

Tabel 1. Hasil Analisis Pendugaan Parameter Faktor Produksi Usahatani Padi di Subak Carik Tangis Tabanan Bali

\begin{tabular}{|c|c|c|c|c|c|}
\hline \multirow{2}{*}{ Faktor produksi } & \multicolumn{2}{|c|}{ Unstandardized coefficients } & \multirow{2}{*}{$\begin{array}{c}\text { Standardized coefficients } \\
\text { Beta }\end{array}$} & \multirow{2}{*}{$\mathrm{t}$} & \multirow{2}{*}{ Sig. } \\
\hline & $\mathrm{B}$ & Std. error & & & \\
\hline Constant & -2.660 & 5.756 & & -.462 & 0,646 \\
\hline Benih Padi $\left(\operatorname{LnX}_{1}\right)$ & 0,482 & 0,230 & 0,234 & 2,100 & 0,041 \\
\hline Luas Lahan $\left(\operatorname{LnX}_{2}\right)$ & 0,163 & 0,072 & 0,088 & 2,257 & 0,023 \\
\hline Pupuk Urea(LnX $\left.{ }_{3}\right)$ & 0,528 & 0,129 & 0,285 & 4,108 & 0,000 \\
\hline PestisidaMatador $\left(\mathrm{LnX}_{4}\right)$ & 0,258 & 0,193 & 0,138 & 1,335 & 0,188 \\
\hline Tenaga Kerja $\left(\operatorname{LnX}_{5}\right)$ & 0,986 & 1.312 & 0,589 & 0,828 & 0,412 \\
\hline Teknologi (LnD) & 0,653 & 0,067 & 0,224 & 9,679 & 0,000 \\
\hline
\end{tabular}

\section{a. Dependent Variable: $\ln Y$}

Jadi, petani padi di Subak Carik Tangis Tabanan Bali disarankan untuk tidak menambah jumlah pestisida matador dan tenaga kerja, karena apabila input tersebut ditambah, tidak akan berdampak secaraa nyata terhadap produksi padi. Dari pengujian atas dasar kriteria ekonomi terhadap parameter-parameter sudah bermakna secara teoritis.

\section{Kriteria Ekonomi}

Kriteria ini ditentukan oleh prinsip-prinsip teori ekonomi. Jika nilai maupun tanda taksiran parameter tidak sesuai dengan kriteria ekonomi, maka taksiran-taksiran itu harus ditolak, kecuali ada alasan kuat untuk menyatakan bahwa dalam kasus ini, prinsip-prinsip ekonomi tidak berlaku, sehingga alasan untuk membenarkan taksiran yang berbeda dengan yang digariskan oleh teori ekonomi harus dinyatakan dengan jelas.

Uji Asumsi Klasik

a. Uji normalitas

Uji normalitas merupakan pengujian data yang dilakukan untuk memenuhi asumsi yang harus dimiliki oleh data yaitu data tersebut terdistribusi secara normal (Santosa, 2005).Uji normalitas bertujuan untuk menguji apakah data penelitian yang dilakukan memiliki distribusi yang normal atau tidak.Uji normalitas dilakukan dengan menggunakan aplikasi SPSS dengan melihat nilai 
$P$-Value, jika nilai $P$-Value $>0,05$ maka data dinyatakan berdistribusi normal. Hasil uji normalitas

Tabel 2. Uji Normalitas One-Sample Kolmogorov-Smirnov Test

\begin{tabular}{llr}
\hline & & Unstandardized Residual \\
\hline $\mathrm{N}$ & Mean & 58 \\
Normal Parameters(a,b) & Std. Deviation &, 0000000 \\
Most Extreme Differences & Absolute &, 14281854 \\
& Positive &, 141 \\
& Negative &, 130 \\
Kolmogorov-Smirnov Z & &,- 141 \\
Asymp. Sig. (2-tailed) & & 1,072 \\
\hline a Test distribution is Normal. &, 201 \\
b Calculated from data. & &
\end{tabular}

Pada Tabel 2 menunjukan nilai $P$-Value $(0,201)>$ 0,05 yang berarti tidak adanya penyimpangan uji asumsi klasik dalam analisis regresi linier, karena data berdistribusi secara normal. b. Uji heteroskedastisitas

Uji heterokedastisitas adalah asumsi dalam regresi dimana varians dari residual tidak sama untuk satu pengamatan ke pengamatan yang lain. Uji heteroskedasitas pada grafik scatterplot dapat dilihat data menyebar secara acak dan tidak membentuk pola tertentu.Hasil uji heteroskedastisitas dapat dilihat pada Gambar 1 berikut ini.

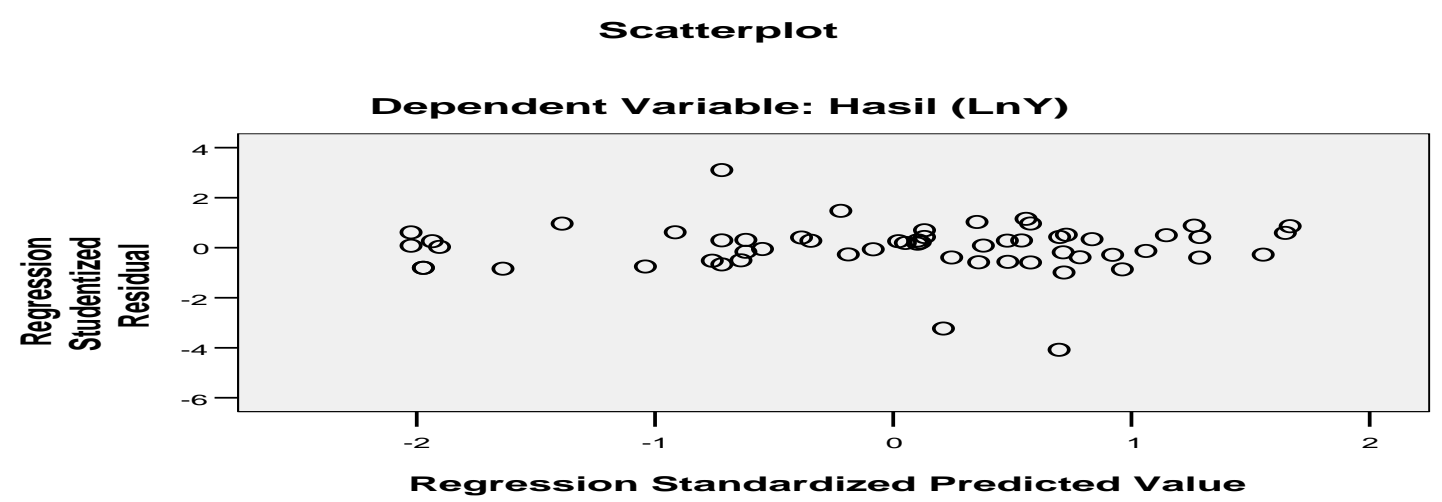

Gambar 1. Uji Heteroskedastisitas pada Grafik Scatterplot

Hasil uji heteroskedastisitas pada Gambar 1 menunjukkan data menyebar secara tidak beraturan dan tidak membentuk pola tertentu.Hal ini menunjukkan bahwa tidak adanya penyimpangan uji

c. Uji multikolinearitas

Pengujian ini bertujuan untuk mengetahui apakah tiap variabel independen saling berhubungan secara linear, apabila sebagian atau seluruh variabel independen berkorelasi kuat berarti terjadi multikolineritas (Gujarati, 2003).Mutikolinearitas ini menyebabkan kesulitan untukmemisahkan pengaruh masing-masing variabel independen terhadap variabel dependen. Gejala multikolinearitas dapat dilihat dari nilai variableinflation factor (VIF). asumsi klasik dalam analisis regresi linier karena tidak ada variabel residual yang bersifat homokedasitas.

Setelah dilakukan uji multikolineritas pada variabelvariabel independen dengan pengukuran terhadapVIF hasilnya menunjukkan bahwa semua variabel independen pada model yang diajukan bebas dari multikolinearitas atau tidak ada multikolinearitas antara variabel independen dalam model. Hal ini ditunjukkan dengan nilai tolerance $>$ 0,1 dan nilai VIF yang $<10$, sehingga dapat dikatakan bahwa persamaan tidak mengandung multikolinearitas, sebagaimana dapat dilihat pada Tabel 3 
Tabel 3. Hasil Uji Multikolinearitas

\begin{tabular}{lcc}
\hline \multicolumn{1}{c}{ Faktor produksi } & Tolerance & VIF \\
\hline Benih Padi $(\operatorname{LnX})_{1}$ & 0,262 & 3,819 \\
Luas Lahan $\left(\operatorname{LnX}_{2}\right)$ & 0,696 & 1,438 \\
Pupuk Urea $\left(\operatorname{LnX}_{3}\right)$ & 0,732 & 1,366 \\
Pestisida Matador $\left(\operatorname{LnX} X_{4}\right)$ & 0,329 & 3,036 \\
Tenaga Kerja $\left(\operatorname{LnX} X_{5}\right)$ & 0,695 & 1,438 \\
Teknologi $(\operatorname{LnD})$ & 0,658 & 1,519 \\
\hline
\end{tabular}

Kriteria Statistik

1. Uji statistik-F

Pengujian terhadap pengaruh variabel independen terhadap variabel dependen dilakukan dengan menggunakan uji statistik-F.Caranya adalah dengan membandingkan antara nilai kritis F-tabel dengan nilai F-hitung yang terdapat pada tabel analysis of variance dari hasil perhitungan SPSS.

Nilai significance pada uji-F yaitu sebesar 0,000 dengan nilai F-hitung sebesar 465,244. Secara rinci hasil uji-F dapat dilihat pada Tabel 4

Tabel 4. Uji-F

\begin{tabular}{lccccc}
\hline \multicolumn{1}{c}{ Model } & Sum of squares & $\mathrm{df}$ & Mean square & F-hitung & Sig. \\
\hline Regression & 63.636 & 6 & 10.606 & 465.244 & $.000^{\mathrm{b}}$ \\
Residual & 1.163 & 51 & .023 & & \\
\hline Total & 64.799 & 57 & & & \\
\hline
\end{tabular}

a. Predictors: (Constant), Benih (LnX1), Luas Lahan (LnX2), Pupuk(LnX3), Pestisida (LnX4), Teknologi (LnD), Tenaga kerja (LnX5),

b. Dependent Varable: Hasil (LnY)

Hasil uji-F pada Tabel 4 menunjukkan nilai $\mathrm{F}$ hitung $=465,244$ dengan significance $\mathrm{F}=0,000$. Hal ini berarti mempunyai kesimpulan yang samadengan $\mathrm{F}_{\text {hitung }}>\mathrm{F}_{\text {tabel(5\%) }}$.

2. Uji statistik-t

Uji statistik-t digunakan untuk mengetahui besarnya pengaruh satu variabel penjelas secara signifikan individual dalam menerangkan variabel

Tabel 5. Uji Parsial (uji-t)
terikatnya.Untuk melihat apakah variabel independen memang benar dapat mempengaruhi variabel dependen secara parsial, untuk itu digunakan uji-t.Untuk menguji apakah Ho diterima atau ditolak, maka dilakukan uji-t, dengan derajat bebas (n-k) dimana ( $\mathrm{n}$ adalah jumlah sampel dan $\mathrm{k}$ adalah jumlah variabel).Secara rinci hasil uji parsial (uji-t) dapat dilihat pada Tabel 5 berikut ini.

\begin{tabular}{lcc}
\hline & Faktor Produksi & Sig. \\
\hline Benih Padi $\left.(\operatorname{LnX})_{1}\right)$ & & 0,041 \\
Luas Lahan $\left(\operatorname{LnX}_{2}\right)$ & 2,100 & 0,023 \\
Pupuk Urea $\left(\operatorname{LnX}_{3}\right)$ & 2,257 & 0,000 \\
Pestisida Matador $\left(\operatorname{LnX}_{4}\right)$ & 4,108 & 0,188 \\
Tenaga Kerja $\left(\operatorname{LnX} X_{5}\right)$ & 1,335 & 0,412 \\
Teknologi $(\operatorname{LnD})$ & 0,751 & 0,000 \\
\hline
\end{tabular}

a. Dependent Variable : Hasil (LnY)

Dari hasil pengolahan data Tabel 5 yang merupakan output dari pengolahanmodel regresi dapat disimpulkan bahwafaktor penggunaan benih $\left(\mathrm{X}_{1}\right)$ yang signifikanpada taraf signifikansi 5\%, karena nilai t-hitung $(2,100)>$ t-tabel $(1,6)$ atau sig. $(0,041)$ $<0,05$, luas lahan $\left(\mathrm{X}_{2}\right)$ pada taraf signifikansi $5 \%$, karena nilai t-hitung $(2,257)>\mathrm{t}$-tabel $(1,6)$ atau sig. $(0,023)<0,05$, faktor pupuk urea $\left(\mathrm{X}_{3}\right)$ yang signifikanpada taraf signifikansi $5 \%$, karena nilai t- hitung $(4,108)>$ t-tabel $(1,6)$ atau sig. $(0,000)<0,05$, faktor teknologi (D) yang signifikanpada taraf signifikansi $5 \%$, karena nilai t-hitung $(9,679)>\mathrm{t}-$ tabel $(1,6)$ atau sig. $(0,000)<0,05$, dan faktor produksi lainnya non signifikan pada taraf signifikansi $5 \%$.

3. Uji koefisien determinasi $\left(\mathrm{R}^{2}\right)$

Koefisien determinasi adalah nilai yang menunjukan besarnya pengaruh faktor produksi penggunaan 
benih padi, luas lahan, pupuk urea, pestisida matador, teknologi dan tenaga kerja secara

Tabel 6. Uji Koefisien Determinasi $\left(\mathrm{R}^{2}\right)$ serempak terhadap produksi padi.Hasil analisis secara rinci dapat dilihat pada Tabel 6berikut ini.

\begin{tabular}{ccccc}
\hline Model & $\mathrm{R}$ & R square & Adjusted $R$ square & Std. error of the estimate \\
\hline 1 & $0,691^{\text {a }}$ & 0,477 & 0,480 & 0,15099 \\
\hline
\end{tabular}

Dari Tabel 6 didapat nilai $R$ square sebesar 0,477 , artinya nilai koefisien determinasi $\left(\mathrm{R}^{2}\right)$ sebesar 0,477 memiliki arti $47,7 \%$ nilai variasi keragaman total hasil produksi padi yang dapat diterangkan oleh faktor produksi dan sisanya 52,3\% dapat diterangkan oleh faktor produksi lainnya yang tidak termasuk dalam analisis.

\subsection{Validasi Model}

Metode peramalan terkecil dapat dinyatakan sebagai metode terbaik untuk meramal. Nilai RMSE yang di dapat sebesar 0,54 dan nilaiMAE yang di dapat sebesar -0,0028, dimana RMSE >MAE, artinya bahwa metode mean absolute error (MAE) lebih baik dalam melakukan peramalan.Dengan nilai MAE sebesar -0,0028. Dengan demikian dapat disimpulkan bahwa uji validasi model sebaiknya

Tabel 7. Hasil Analisis Regresi Linier Berganda menggunakan metode mean absolute error (MAE), karena mempunyai akurasi yang baik.

\subsection{Aplikasi dan interpretasi model}

Berdasarkan nilai koefisien regresi dari masingmasing faktor produksi, maka dapat diketahui apakah dengan menambah satu satuan faktor produksi dapat meningkatkan atau menurunkan produksi.Pedoman yang digunakan dalam menentukan adanya peningkatan atau penurunan produksi ini adalah dilihat dari tanda positif atau negatif dari nilai koefisien regresi.Tanda positif berarti terjadi peningkatan produksi, sedangkan tanda negatif berarti terjadi penurunan produksi.Hasil analisis secara rinci dapat dilihat pada Tabel 7 berikut ini.

\begin{tabular}{lcc}
\hline \multicolumn{1}{c}{ Faktor produksi } & B & Std. error \\
\hline Benih Padi $(\operatorname{LnX})_{1}$ & 0,482 & 0,230 \\
Luas Lahan $\left(\operatorname{LnX} X_{2}\right.$ & 0,163 & 0,072 \\
Pupuk Urea $\left(\operatorname{LnX}_{3}\right)$ & 0,528 & 0,129 \\
Pestisida Matador $\left(\operatorname{LnX} X_{4}\right)$ & 0,258 & 0,193 \\
Tenaga Kerja $(\operatorname{LnX})_{5}$ & 0,986 & 1.312 \\
Teknologi $(\operatorname{LnD})$ & 0,653 & 0,067 \\
\hline
\end{tabular}

Dari hasil pengolahan data Tabel 7 dapat disimpulkan:

1. Benih Padi $\left(\mathrm{X}_{1}\right)$ memiliki nilai koefisien regresi yang positif sebesar 0,482, artinya setiap penambahan benih sebesar $1 \mathrm{~kg}$ akan meningkatkan produksi padi sebesar $0,482 \mathrm{~kg}$. Hal ini diduga dengan menambah penggunan benih padi lokal, maka akan meningkatkan hasil produksi padi, sehingga penggunaan benih perlu ditambah agar produksi padi tetap optimal.

2. Luas Lahan $\left(\mathrm{X}_{2}\right)$ memiliki nilai koefisien regresi yang positif sebesar 0,163 , artinya setiap penambahan luas lahan sebesar $1 \%$ akan meningkatkan produksi padi sebesar $0,163 \%$. Hal ini diduga dengan menambah jumlah luas lahan, maka akanmeningkatkanhasilproduksi padi, sehingga penggunaan luas lahan perlu ditambah agar produksi padi tetap optimal.

3. Pupuk urea $\left(\mathrm{X}_{3}\right)$ memiliki nilai koefisien regresi yang positif sebesar 0,528 , artinya setiap penambahan pupuk sebesar $1 \%$ akan meningkatkan produksi padi sebesar $0,528 \%$. Hal ini diduga dengan menambah pupuk, maka akan meningkatkan hasil produksi padi, sehingga penggunaan pupukperlu ditambah agar produksi padi optimal.

4. Pestisida matador $\left(\mathrm{X}_{4}\right)$ tidak berdampak (non signifikan) terhadap produksi. Hal ini berarti dengan menambah pestisida, tidakakan merubah hasil produksi padi, sehingga penggunaan pestisida tidak perlu ditambah.

5. Tenaga Kerja $\left(\mathrm{X}_{5}\right)$ tidak berdampak(non signifikan) terhadap produksi padi. Hal ini berarti dengan menambah penggunaan tenaga kerja, tidak akan meningkatkan hasil produksi padi di Desa Subak Carik Tangis Wongaya Gede.

6. Penggunaan teknologi (D)oleh petani akan lebih besarhasil produksinya sebesar 0,653 dibandingkan dengan petani yang tidak menggunakan teknologi. 


\section{Efisiensi Faktor Produksi Padi}

Tabel 8. Hasil Analisis Efisiensi Teknis

\begin{tabular}{llll}
\hline Faktor produksi & Nilai Koefisien & Daerah Elastisitas & Keterangan \\
\hline Benih Padi & 0,482 & Daerah II & Efisiensi Secara Teknis \\
Luas lahan & 0,163 & Daerah II & Efisiensi Secara Teknis \\
Pupuk Urea & 0,528 & Daerah II & Efisiensi Secara Teknis \\
Pestisida Matador & 0,258 & Daerah II & Efisiensi Secara Teknis \\
Tenaga Kerja & 0,986 & Daerah II & Efisiensi Secara Teknis \\
\hline
\end{tabular}

Dalam hal ini efisiensi teknis telah tercapai pada faktor dan benih padi $\left(\mathrm{X}_{1}\right)$, luas lahan $\left(\mathrm{X}_{2}\right)$, pupuk urea $\left(\mathrm{X}_{3}\right)$, pestisida matador $\left(\mathrm{X}_{4}\right)$ dan tenaga kerja $\left(\mathrm{X}_{5}\right)$,karena penambahan faktor produksi akan

Tabel 9. Hasil Analisis Efisiensi Harga menyebabkan meningkatnya hasil produksi. Secara rinci hasil efisiensi harga dapat dilihat pada Tabel 5.15 berikut ini.

\begin{tabular}{lcl}
\hline \multicolumn{1}{c}{ Faktor produksi } & Efisiensi & \multicolumn{1}{c}{ Keterangan } \\
\hline Benih Padi & 0,48 & Tidak efisien (Berlebih) \\
Luas lahan & 3,26 & Belum efisien (Masih rendah) \\
Pupuk Urea & 6,25 & Belum efisien (Masih rendah) \\
Pestisida Matador & 0,44 & Tidakefisien (Berlebih) \\
Tenaga Kerja & 0,60 & Tidak efisien (Berlebih) \\
\hline
\end{tabular}

Dari Tabel 9 dapat dilihat bahwa semua penggunaan faktor produksi tidak efisien, karena nilai NPMxi/Pxi faktor produksi ada yang lebih dari 1 yaitu luas lahan, dan pupuk urea belum efisien (masih rendah), sedangkan pestisida matador, tenaga kerja dan benih padi kategori tidak efisien (berlebih).Hal ini memperlihatkan bahwa penggunaan input pada usahatani padi belum mencapai tingkat efisiensi harga dan luas lahan kategori belumefisien. Dalam hal ini apabila petani mampu mencapai efisiensi, maka petani akan

Tabel 10. Hasil Analisis Efisiensi Ekonomis mampu meningkatkan produksi padi, sehingga keuntungan petani juga akan semakin meningkat.

Efisiensi ekonomis (EE) adalah hasil kali antara efisiensi teknis dikali dengan efisiensi harga dari seluruh faktor input (Epp \& Malone, 1981). Dalam penelitian ini bilamana dapat mencapai efisiensi ekonomis bilamana usaha pertanian tersebut mencapai efisiensi teknis sekaligus efisiensi harga.Secara rinci hasil efisiensi ekonomis dapat dilihat pada Tabel 10 berikut ini.

\begin{tabular}{ccccc}
\hline Faktor produksi & $\begin{array}{c}\text { Efisiensi } \\
\text { Teknis }\end{array}$ & $\begin{array}{c}\text { Efisiensi } \\
\text { Harga }\end{array}$ & $\begin{array}{c}\text { Efisiensi } \\
\text { Ekonomis }\end{array}$ & Kesimpulan \\
\hline Benih Padi & 0,320 & 0,48 & 0,15 & Tidak efisien \\
Luas lahan & 0,151 & 3,26 & 0,49 & Tidak efisien \\
Pupuk Urea & 0,423 & 6,25 & 2,64 & Belum efisien \\
Pestisida Matador & 0,120 & 0,44 & 0,05 & Tidak efisien \\
Tenaga Kerja & 0,576 & 0,60 & 0,35 & Tidak efisien \\
\hline
\end{tabular}

BerdasarkanTabel 10 diketahui bahwa semua faktor produksi tidak ada yang efisien dalam usahatani padi di Subak Carik Tangis Tabanan Bali, artinya penggunaan input yang tidak optimal, sehingga petani padibelum memperoleh keuntungan yang maksimal. Sebaiknya dilakukan penggunaan input secara tepat sehingga petani akan mampu memperoleh keuntungan yang maksimal. Untuk mencapai efisiensi maka penggunaan input dapat ditambah atau dikurangi, sehingga memperoleh produksi dan keuntungan yang optimal. Dengan tidak efisiennya semua faktor produksi, maka petani perlu memperhatikan penggunaan faktor produksi agar lebih tepat, sehingga petani padi mampu mencapai efisiensi. 


\section{KESIMPULAN DAN SARAN}

\section{Kesimpulan}

Berdasarkan hasil analisis dan pembahasan, maka dapat diperoleh kesimpulan sebagai berikut:

1. Secara bersama-sama semua factor produksi padi yang dimasukan ke dalam fungsi produksi Cobb-Douglas dalam usahatani padi tidak semuanya berpengaruh nyata terhadap produksi padi. Secara parsial factor produksi benih padi, luas lahan, pupuk urea dan teknologi berpengaruh nyata terhadap produksi padi. Secara parsial faktor pestisida matador dan tenaga kerja tidak berpengaruh nyata terhadap produksi padi.

2. Berdasarkan hasil analisis efisiensi teknis, factor benih padi efisien, luas lahan, pupuk urea, pestisida matador, tenaga kerja secara teknis. Ditinjau dari efisiensi harga, faktor produksi luas lahan dan pupuk urea belum efisien dimana dalam hal ini pemakian input masih rendah sehingga perlu ditambah untuk memperoleh keuntungan yang maksimal, sedangkan faktor produksi pestisida matador, tenaga kerja dan benih padi tidak efisien, dimana dalam hal ini pemakaian input digunakan secara berlebihan sehingga perlu dikurangi untuk memperoleh keuntungan yang maksimal. Ditinjau dari efisiensi ekonomis semua faktor produksi tidak ada yang efisien yang artinya penggunaan input yang tidak optimal, sehingga petani belum memperoleh keuntungan yang maksimal.

\section{Saran}

Saran yang dapat diberikan untuk petani, pemerintah, maupun peneliti lainnya sebagai berikut.

1. Jika petani ingin hasil produksi padi berpengaruh nyata, maka petani padi di Subak Carik TangisWongaya Gede Tabanan perlu memikirkan faktor produksi yang akan digunakan untuk memperoleh keuntungan yang akan meningkatkan hasil produksi padi secara maksimal.

2. Dalam melakukan usahatani padi, petani perlu memperhatikan faktor-faktor yang mempengaruhi produksi padi sehingga dapat mencapai efisiensi dalam usahatani padi. Penggunaan faktor produksi perlu dilakukan secara tepat, sehingga petani mampu mencapai efisiensi.

3. Bagi peneliti yang akan melakukan penelitian di Subak Carik Tangis, maka perlu dilakukan penelitian lanjutan tentang "Efisiensi Penggunaan Faktor Produksi Padi Organik" dan "Strategi Pemasaran Hasil Produksi PadiKhususnya Beras Merah".

\section{DAFTAR PUSTAKA}

Epp, D.J. and J.W. Malone, Jr. 1981.Introduction to Agricultural Economics. Mac Millan Publishing Co, Inc. New York.

Gujarati. 2003. Ekonometrika Dasar, Erlangga. Jakarta.

Miller, R. J and Roger E Meiners. 2000. Teori Mikroekonomi Intermediate. Jakarta: PT. Raja Grafindo Persada.

Soekartawi, 2005. Prinsip Dasar Ekonomi Pertanian : Teori dan Aplikasi, Edisi Kedua, Cetakan Keempat. PT. Raja Grafindo Persada, Jakarta.

Vink, G.J.. 1984. Dasar-Dasar Usaha Tani di Indonesia. Jakarta: Terjemahan Yayasan Obor.

Widowati, Endang. 2007. "Analisis Ekonomi Usahatani Padi Organik Di Kabupaten Sragen", Tesis, MESP UNS, Surakarta. 